\title{
Learning from contemporary examples in Africa
}

\author{
Referral mechanisms for \\ restorative justice in Tanzania
}

\author{
Ntemi N Kilekamajenga* \\ kilekamajenga@yahoo.co.uk \\ http://dx.doi.org/10.17159/2413-3108/2018/i63a4368
}

Tanzania is one of the jurisdictions in Africa that follow an adversarial criminal justice system. Despite a number of problems associated with the fact that the criminal justice system overutilises imprisonment, there is still a lack of diversionary measures to complement the system. This article investigates restorative justice as a complementary system to the Tanzanian criminal justice system, arguing that the law, including the constitution of the country, favours the application of restorative interventions. Invoking restorative justice mechanisms can, inter alia, relieve over-laden courts from the backlog of minor cases, and can help the government salvage funds by reducing the number of incarcerated offenders. It is further argued that restorative justice approaches that have been articulated in some juvenile justice systems in Africa can be adapted to suit the Tanzanian restorative approach for child and adult offenders.

I cannot easily erase the memory of a criminal case I witnessed at one of the primary courts in Tanzania. As a lecturer at the Institute of Judicial Administration in Lushoto, Tanzania, I supervised law students who went for field attachment as primary court ${ }^{1}$ magistrate trainees in Moshi. While there, I attended a session of a criminal case out of curiosity. The accused in the case was a young woman,

\footnotetext{
* Ntemi Nimilwa Kilekamajeng is a lecturer at the Institute of Judicial Administration in Lushoto, Tanzania and an LLD Student at the University of Pretoria. He holds an LLM in International Economic and Business Law from Kysuhu Univerity in Japan (2007), an LLM in Law and IT from Stockholm University (2004) and an LLB from the University of Dar es Salaam (2001). The author would like to thank Prof. Ann Skelton for her helpful comments on drafts of this article.
}

possibly a few months older than 18 years of age, who was being prosecuted for stealing some well-worn clothes and 10000 Tanzania shillings (approximately \$5) from her sister's bag. The complainant, the accused's sister, had only one witness - their uncle. As is custom at the start of a trial, the charge was read to the accused, who pleaded not guilty, and the matter proceeded for hearing. As the rules of the adversarial system require, the complainant adduced the facts of the incident. Thereafter, the accused young woman got an opportunity to cross-examine the complainant. Unaware of the technicalities of the adversarial criminal justice system, she remained silent for a while, and then told the court that she 
had no questions. Then, the witness (their uncle) testified, and again, the accused did not contradict her uncle's testimony during crossexamination. The case was finally adjourned to allow the young woman to prepare her defence. Thereafter, I met one of the magistrates to enquire about diversion measures available at primary courts. She was doubtful and uncertain, and had many questions about the implementation of reconciliatory measures, despite the fact that the court's rules promote reconciliation in certain cases. ${ }^{2}$ It struck me that the case that I had just witnessed was precisely the kind of case the rules envisaged in mandating the use of restorative measures.

Restorative justice has featured for over three decades in academic and professional discourses as a complementary approach in many jurisdictions where it has been adopted. ${ }^{3}$ In Africa the implementation of restorative justice within or alongside criminal justice systems has been slow, despite the fact that restorative justice is similar to traditional justice. ${ }^{4}$ Tanzania, which has an adversarial criminal justice system, faces many challenges, including overcrowding in prisons and a backlog of court cases. ${ }^{5}$ These trends are likely to worsen if new mechanisms of justice are not put in place. A restorative justice approach holds promise as a complementary mechanism to the criminal justice process in Tanzania. This article therefore examines the definitions of restorative justice and discusses referral mechanisms in contemporary juvenile laws in South Africa, Uganda, Lesotho and Kenya. The article examines whether these jurisdictions can provide a model for the establishment of restorative justice mechanisms in Tanzania.

\section{Restorative justice and its advantages}

Restorative justice seeks to knit together the victim, offender, family members, 'community of care' ${ }^{6}$ and the community in the decision- making process following an offence. ${ }^{7}$ The process ensures the offender's accountability; ${ }^{8}$ and is aimed at making things right, ${ }^{9}$ achieving repair and reconciliation, and preventing future re-offending..$^{10}$ It is generally a justice paradigm that advocates for redefining crime ${ }^{11}$ and giving voice to the affected parties in the justice process. ${ }^{12}$ Under restorative justice, crime is more than the violation of the laws of the country; it is, rather, a violation of relationships between individuals that creates needs and obligations. ${ }^{13}$ The victim is no longer the state but is recognised as an individual, family members and the community. All of these actors are appreciated as having directly or indirectly suffered harm, ${ }^{14}$ and they come together to resolve the dispute in an amicable way. ${ }^{15}$ The victim is given a voice in the process to speak about his or her suffering ${ }^{16}$ and to talk about the effects of the crime, including financial, psychological and emotional effects, which may normally not be addressed in criminal courts. ${ }^{17}$

Restorative justice fundamentally aims at restoring shattered relationships between individuals, and initiates a healing process. ${ }^{18}$ In the process, the victim's needs are addressed and the offender acknowledges responsibility ${ }^{19}$ and is given an opportunity to empathise with the victim and apologise for wrongdoing. ${ }^{20}$ Parties are therefore no longer observers of their own justice ${ }^{21}$ but become key role players instead. ${ }^{22}$ Because restorative justice is a process that involves the affected parties in a facilitated discussion about the crime and its causes, ${ }^{23}$ it allows parties to empathise, reconcile, apologise, forgive, ${ }^{24}$ repent and repair harms. ${ }^{25}$ Even where offenders are not willing to be involved in a restorative intervention during the trial phase, they can still participate in restorative justice initiatives later on in prison, especially where jurisdictions offer these programmes as a rehabilitative process or as a process towards prisoners' early release or parole. ${ }^{26}$ 
Restorative justice also responds better to the needs of justice stakeholders than the contemporary criminal justice system ${ }^{27}$ - even, some have suggested, in the case of serious offences. ${ }^{28}$ After the offender makes amends through restorative justice, the victim is relieved of the fear of re-victimisation. ${ }^{29}$ Van Ness and Strong argue that restorative justice works better in terms of offenders' rehabilitation than the prison system. ${ }^{30}$ Restorative justice prepares the offender for reintegration into society or the community where he or she was initially stigmatised, ${ }^{31}$ and helps to reduce recidivism. ${ }^{32}$ Sharman and Strang show that restorative justice reduces revenge among victims, ${ }^{33}$ and Koen argues that these processes help to achieve social harmony among members of the community by reconciling conflicts. ${ }^{34}$ Studies also show greater satisfaction with the restorative justice process than pursuing justice through court processes, for both offenders and victims. ${ }^{35}$ Parties can avoid court processes and the associated costs, ${ }^{36}$ and the government is relieved of the costs of imprisoning offenders. ${ }^{37}$ Given these advantages, using a restorative process alongside the contemporary criminal justice system appears to hold some promise.

\section{Challenges of using restorative justice}

There are, however, several challenges that need to be considered if Tanzania seeks to implement restorative justice mechanisms. Limited space allows us to address only a few of these challenges here.

First, the process may need funding, either by the government or through non-governmental organisations. Judges, magistrates and police will need to be trained, and communities will need to be sensitised to the model.

Second, involving the community in justice delivery, if not monitored, may turn restorative justice processes into ones that place rights at risk. ${ }^{38}$ Depending on a community's beliefs, some offences may be treated more leniently than others. ${ }^{39}$ Furthermore, inequalities based on 'wealth, gender, race, ancestry and family connections' can affect a restorative process if the community is involved. ${ }^{40}$ In modern societies where communities are organised and managed by the state, the word 'community' has become contentious, ${ }^{41}$ which makes restorative justice principles more difficult to implement because of weak social bonds.

Third, some offences such as serious crimes, domestic violence, sexual violence and hate crimes are difficult to manage in restorative justice processes. ${ }^{42}$ While victims of sexual violence find the adversarial criminal justice process traumatising, ${ }^{43}$ restorative justice processes may not fare any better. ${ }^{44}$ In sexual offence cases, the re-telling of the story by the victim may be experienced as either therapeutic ${ }^{45}$ or traumatic. ${ }^{46}$ Community perceptions about the gendered impact of patriarchy remain a challenge. Despite promising evidence on the use of restorative justice in violent offences, ${ }^{47}$ community acceptance of restorative justice alternatives for serious offences remains difficult to achieve. ${ }^{48}$

The fourth challenge relates to whether restorative justice addresses the needs of victims. Some criminologists have argued that these processes are a ploy to achieve offenders' rehabilitation and reduce criminality with scant regard for restoration or justice for victims. Strang, for example, sees victims as 'court fodder' under the conventional criminal justice system, and holds that they become 'agents' of offenders' reformation under restorative justice. ${ }^{49}$ Even a victim's face-to-face encounter with his or her offender may actually only benefit the offender's rehabilitation, and it is difficult to strike a balance between maintaining the rights of each party. ${ }^{50}$ While communities may like to re-integrate reformed offenders, this should not come at the cost of the victim. ${ }^{51}$ 
The final challenge raised here is the fact that restorative justice does not depend on the rules of evidence ${ }^{52}$ or precedent. ${ }^{53}$ Because the dispute is normally diverted to restorative interventions after the offender admits responsibility, witnesses may not be required to prove the offence. The offence is therefore resolved on the basis of the parties' identified needs. As a result, there are no uniform outcomes from restorative justice processes. ${ }^{54}$ This flexibility makes restorative processes attractive for attending to the needs of justice stakeholders without being bound to legal rules. Also, the idea of having 'standards' for restorative justice is difficult because every community has norms; such norms may be influential in conducting restorative justice processes. ${ }^{55}$ The flexibility of restorative justice also provides an opportunity to accommodate a wider range of facts, some of which may not be accepted in court. Because restorative justice has no uniform standards of dispute resolution, outcomes may vary. ${ }^{56}$ Some consider this outcome disparity as latitude for 'inequality', 'inconsistency' and 'arbitrariness' in the process of justice. ${ }^{57}$ Proponents of restorative justice have countered that even courtroom justice does not guarantee uniform decisions, and despite following precedent, each case is decided on its merits.

\section{Referral mechanisms for juvenile justice}

Modern restorative justice allows for the diversion of criminal cases at any stage during the justice process: pre-trial, pre-sentence, at sentencing or post sentencing. ${ }^{58}$ Processes such as victim offender mediation, family group conferencing and conferencing circles are mostly restorative pre-trial or pre-sentencing procedures, but this does not mean that they cannot be used at the sentencing stage or for incarcerated offenders. ${ }^{59}$ The point at which restorative justice processes are applied differs from one jurisdiction to another and also depends on the nature of the offence. ${ }^{60}$ Additionally, youth justice processes make use of restorative justice in a number of jurisdictions, and these could serve as models for restorative mechanisms in adult cases.

New Zealand allows juvenile offenders to be diverted to restorative intervention at the police or court level. ${ }^{61}$ Police diversion (also called police cautioning) occurs after an offender has been arrested but before prosecution, and can take various forms; from a warning not to reoffend through to arrest and being charged in court. The process therefore diverts an offender who would usually be taken through the court process. In countries such as the United Kingdom and Australia, police cautioning is generally conducted in minor offences, ${ }^{62}$ but can also be applied even in serious offences. ${ }^{63}$

South Africa has a different model for restorative interventions for child offenders. The Child Justice Act gives powers to the prosecutor to divert a case to a restorative justice process, ${ }^{64}$ especially when the offender has admitted responsibility and has consented to diversion. ${ }^{65}$ The proposal by the prosecutor to divert the case to restorative intervention takes effect after a court order. ${ }^{66}$

Restorative justice in South Africa has been extended to cases involving adult offenders through case law. ${ }^{67}$ For adult offenders, the law also provides an opportunity for the magistrate to refer the matter to restorative measures where there are good reasons to do so. Furthermore, under the South African Criminal Procedure Act, the magistrate can request, after the conviction but before sentencing, information necessary for arriving at a judicious sentence. ${ }^{68}$ Between conviction and sentencing there is then time for the magistrate to allow other processes, such as restorative justice, to take place before the offender is sentenced. ${ }^{69}$ If restorative justice is conducted at this stage, the agreement 
reached during the meeting of parties assists the magistrate in setting a sentence. ${ }^{70}$ Based on the input from the victim, the offender and the community as part of the agreement reached through the restorative justice process, ${ }^{71}$ the magistrate can order a suspended sentence, community service, fine or compensation in lieu of imprisonment.

Other countries in Africa such as Uganda, South Sudan and Lesotho use diversionary measures for juvenile justice that involve customary law conflict resolution. First, the Ugandan Executive Committees (Judicial Powers) Act gives civil and criminal jurisdiction to local councils to resolve cases originating from their territorial jurisdictions. ${ }^{72}$ Second, the Ugandan Children's Statute allows a case involving a juvenile offender to be diverted to village courts for determination. Such councils facilitate reconciliation, compensation, restitution, caution and other restorative remedies for the parties. ${ }^{73}$ Involving the community (village courts) as a diversionary measure also aims to shame, reform and reintegrate the child back into the community. ${ }^{74}$ In South Sudan, a jurisdiction that embraces traditional justice in many aspects of the criminal justice system, the law offers restorative justice interventions for child offenders. ${ }^{75}$ Under the Child Act, traditional justice systems handle many minor cases involving juvenile offenders, while serious offences are tried by formal courts. ${ }^{76}$

In Kenya, though the law does not explicitly provide for restorative justice for juvenile offenders, the Children's Act has some provisions that divert a child offender from ordinary court processes to restorative remedies such as the payment of a fine, compensation, or community service. These remedies may also include that the child is placed under foster care, attends rehabilitation school or sees a qualified counsellor. ${ }^{77}$ Under the Tanzanian juvenile justice system, though restorative justice only applies as part of conditional discharge, ${ }^{78}$ imprisonment of a child for whatever term is restrained. ${ }^{79}$ Instead, alternative sentences are issued such as a fine, compensation, ${ }^{80}$ probation order, ${ }^{81}$ conditional discharge, ${ }^{82}$ or committal to an approved school. ${ }^{83}$ In Lesotho, with its strong system of indigenous justice, ${ }^{84}$ a restorative approach has been adopted in the Children's Protection and Welfare Act of 2011. ${ }^{85}$ Like the Ugandan Child Statute, the law in Lesotho allows the application of restorative approaches through village child justice committees, a model that brings together international legal norms and a traditional justice ethos in a way that is 'more promotional or protective of the rights of children'. ${ }^{86}$ In these jurisdictions - Uganda, South Sudan and Lesotho - the use of restorative justice for adult offenders is still minimal, even though their youth justice frameworks provide evidence in favour of the implementation of restorative mechanisms.

\section{The law in Tanzania and the possibilities for restorative justice}

Under the Constitution of the United Republic of Tanzania (the Constitution), the judiciary is mandated to dispense justice ${ }^{87}$ without fear or favour. ${ }^{88}$ In so doing, in both civil and criminal matters, the courts have several powers, which include awarding reasonable compensation to victims of crimes committed by offenders, and taking into account the nature of the case and the harm caused. ${ }^{89}$ In practice, victim compensation in Tanzania is usually coupled with imprisonment. However, filing a compensation claim only when offenders are released after serving a prison sentence may be difficult, because of the time that has lapsed. Furthermore, it is complicated to execute a civil order against an incarcerated offender, as she or he may not be able to pay compensation because she or he is not working or earning any income in prison. The courts therefore often 
award compensation alongside other orders immediately after finding the offender guilty. This may relieve the victim of the hassle of filing a second lawsuit, and saves time and money for both victim and the state. Victims view compensation orders as an acknowledgement by the court that they have been affected by the crime. These orders can include, for example, compensation for the victim's medical expenses. Although the monetary value of these compensation orders may frequently not be equivalent to the actual amount of harm suffered by the victim, their symbolic nature may suffice to make things right. Courts are also vested with constitutional powers to "promote and enhance dispute resolution among persons involved in dispute, ${ }^{90}$ and this provision envisages an amicable dispute settlement between victim and offender. The Constitution mandates that the courts should not be 'tied up with technicalities provisions that may obstruct dispensation of justice'. ${ }^{91}$

The spirit of reconciliation provided by the Tanzanian Constitution is directly reflected in the Criminal Procedure Act, which gives discretion to courts that:

[l]n the case of proceedings for common assault or for any other offence of a personal or private nature the court may, if it is of the opinion that the public interest does not demand the infliction of a penalty, promote reconciliation and encourage and facilitate the settlement, in an amicable way, of the proceeding or the terms of payment of compensation or other terms approved by the court, and may thereupon order the proceedings to be stayed. ${ }^{92}$

This provision gives powers to courts to divert certain cases, especially cases of common assault and those of a personal or private nature, from the ordinary adversarial criminal justice processes to ones focused on reconciliation. ${ }^{93}$ Diversion therefore seeks to promote reconciliation in an amicable and harmonious way, ${ }^{94}$ and in so doing, stay the proceedings until an agreement is reached. ${ }^{95}$ In reconciling the parties, compensation to the victim may be awarded and punitive measures may be waived. ${ }^{96}$ Where reconciliation fails, the court may proceed with the normal trial. Similarly, rule 4(2) of the Primary Courts Criminal Procedure Code echoes the provisions of the Criminal Procedure Act ${ }^{97}$ (although reconciliation is not defined), obliging courts to promote reconciliation in criminal cases. ${ }^{98}$ According to this law, where reconciliation is reached, the complainant may withdraw the charge..$^{99}$

Unfortunately, though, these provisions in law have rarely been used or are implemented problematically. The first major impediment to implementing the options envisaged by the law is the lack of restorative justice programmes into which to divert cases. Second, reconciliation is normally left in the hands of the parties, without a mediator. ${ }^{100}$ Although it would be preferable to have an impartial mediator to guide the restorative justice process, in practice this is normally left to family members who are also interested parties in the dispute. Third, the courts are not bound to divert a case for reconciliation - these provisions are discretionary. As a result, the law has been used in only a few cases, despite the fact that there are many offences which may be fit for reconciliation. Finally, as is alluded to in the introduction to this article, some magistrates may not be aware of the option of diversionary alternatives and hence they find it hard to order an out-of-court reconciliation.

\section{Restorative justice practices under the ward tribunals in Tanzania}

Tanzania has a history of reconciliation through ward tribunals. ${ }^{101}$ According to the establishing Act, every ward has a tribunal to determine civil and criminal cases through mediation. ${ }^{102}$ The tribunals were specifically established to 
secure peace and harmony at grassroots level through mediation. ${ }^{103}$ They were also meant to relieve the primary courts from backlogs of cases by sifting cases before going to a primary court. ${ }^{104}$ The tribunal is composed of four to eight members elected by the ward committee, with the chairperson and secretary appointed from the elected members. ${ }^{105}$ The chairperson plays the role of a mediator, and other members act as representatives of the community.

Any person, including family members of the victim and the offender, may attend and give evidence. ${ }^{106}$ Of course, the rules of evidence are unlike those of the courts ${ }^{107}$ - even where there is insufficient evidence, the offender may still be held accountable. Compensation, restitution, apologies, fines, corporal punishment and community service are normally awarded or imposed by the ward tribunals. ${ }^{108}$ Parties who are aggrieved by the tribunal's decision can appeal to the primary court. ${ }^{109}$

The major difference between the ward tribunals and the primary courts is the procedure for dispute resolution. While mediation and reconciliation are features of the ward tribunals in both civil and criminal cases, the primary courts follow adversarial procedures. ${ }^{110}$ Lawi argues that when ward tribunals were properly working as dispute resolution organs, there was evidence of true reconciliation and satisfaction between the involved parties. ${ }^{111}$ Although these tribunals operate under local government authority in Tanzania, they hold promise as a prototype of restorative interventions that could ease the burden of Tanzania's laden courts. Unfortunately, in reality, the ward tribunals envisaged by the law are ineffective owing to a lack of financial support from local governments. Currently, because of the community need for accessible justice, administrative staff from the wards, especially ward executive officers, have taken over the reconciliation role that was entrusted to ward tribunals under the law, ${ }^{112}$ which means that the tribunals are no longer composed as set out in the law. For these tribunals to work properly as restorative justice programmes, it will require that they are reconstituted in accordance with the law, and that the appropriate funds are allocated to support their operation.

\section{Conclusion and recommendations}

Despite the promising opportunities provided under the Tanzanian Constitution, the Criminal Procedure Act and the rules of the primary courts, restorative justice is not viewed as a formal complementary mechanism that can provide justice or relieve the country's over-burdened criminal justice system. Even minor offences, which could be resolved out of court, are still brought to court for prosecution. The number of prisoners in Tanzania exceeds the capacity of the prisons ${ }^{113}$ and, as a result, government has continued to pardon a large number of prisoners during public anniversaries. ${ }^{114}$ It is questionable how these prisoners are prepared for reintegration after prison, given that there is also a lack of restorative interventions for incarcerated offenders. Pardoned offenders face stigma from their communities because they have not had the opportunity to right their wrongs. The security of victims is also threatened by the release of offenders who have not been exposed to programmes that can help them realise the effects of their crimes.

Tanzania is not the only country experiencing these problems or high levels of reoffending by released offenders. This article points to juvenile justice models in other countries such as New Zealand, South Africa, Lesotho and South Sudan that may show how these problems might be reduced. ${ }^{115}$ Based on the above discussion, the following recommendations could be adopted by the Tanzanian government, and may be instructive elsewhere on the African continent: 
First, prosecutors should have the discretion to divert cases to a restorative justice process before charging the offender, especially where there are good reasons to do so. This will reduce the number of cases for prosecution and hence relieve courts from a backlog of minor cases. Implementation of this proposal may not necessarily need law reform, as directives that underscore prosecutorial discretion may be enough.

Second, police stations may be appropriate centres for diversion through cautioning, if proper training in restorative justice is provided. After cautioning, the police can keep records of the cautioned offender for future reference. This may be a national approach towards the implementation of restorative justice interventions.

Third, courts should make use of current provisions of the law by diverting offenders who have pleaded guilty into restorative interventions. This would allow the offender an opportunity to make things right with the victim and the community, and allows the magistrate to use the recommendations from restorative meetings when sentencing the offender.

Fourth, the courts can sentence an offender to a restorative justice process, provided both victim and offender voluntarily agree.

Fifth, ward tribunals can be strengthened to deliver reconciliation programmes for all wards in the country, provided that the system is properly resourced and special training is offered to ensure that the tribunals work according to the principles of restorative justice envisaged under the law

To comment on this article visit

http://www.issafrica.org/sacq.php

\section{Notes}

1 A primary court is the lowest court in the judicial hierarchy in Tanzania.
2 Tanzania, Primary Courts Criminal Procedure Code, Rule 4. This is the law governing criminal conduct in the primary courts.

3 See TF Marshall, Restorative justice: an overview, in G Johnstone (ed.), A restorative justice reader: texts, sources, context, Milton: Willan Publishing, 2003, 31.

4 Only a few African countries have adopted principles of restorative justice processes alongside the criminal justice process. These countries include South Africa, Uganda, Lesotho and Zimbabwe. See DW Van Ness and KH Strong, Restoring justice: an introduction to restorative justice, $4^{\text {th }}$ edition, Cincinnati: Anderson Publishing, 2010, 33-8; NT Qhubu, The development of restorative justice in Lesotho, Association of Law Reform Agencies of Eastern and Southern Africa, http://www.justice.gov.za/alraesa/conferences/2005sa/ papers/s4B_qhubu.pdf (accessed 12 July 2017).

5 Tanzanian prison capacity is 29552 while it currently holds 33000 inmates. Half of the inmates are awaiting trial. Legal and Human Rights Centre and Zanzibar Legal Services Centre, Tanzania human rights report 2016, 2017, 157.

6 'Community of care' is a term used to describe persons indirectly affected by the crime, such as teachers, colleagues, friends, neighbours, etc. See Van Ness and Strong, Restoring justice, 43, 44.

7 DJ Schmid, Restorative justice: a new paradigm for criminal justice policy, Victoria University of Wellington Law Review VUWLR, 34:1, 2002, 93.

8 M Wright, Restorative justice: the basic idea, and practice in the United States, in E Fattah and S Parmentier (eds), Victim policies and criminal justice on the road to restorative justice, Leuven: Leuven University Press, 2001, 355.

9 Ibid., 355.

10 Marshall, Restorative justice, 5; G Johnstone and DW Van Ness, The meaning of restorative justice, in G Johnstone (ed.), A restorative justice reader, $2^{\text {nd }}$ edition, London: Routledge, 2013, 12.

11 Schmid, Restorative justice, 94.

$12 \mathrm{R}$ Young and $\mathrm{C}$ Hoyle, Restorative justice and punishment, in S McConville (ed.), The use of punishment, Milton: Willan Publishing, 2003, 200.

$13 \mathrm{H}$ Zehr, Changing lenses: a new focus for crime and justice, $3^{\text {rd }}$ edition, Scottdale: Herald Press, 2005, 181.

14 Van Ness and Strong, Restoring justice, 43.

15 Schmid, Restorative justice, 93.

16 D Roche, Accountability in restorative justice, New York: Oxford University Press, 2003, 2, 32.

17 G Pavlich, Governing paradoxes of restorative justice, New York: Routledge, 2005, 2; Roche, Accountability in restorative justice, 10.

18 Zehr, Changing lenses, 186.

19 lbid., 43.

20 Schmid, Restorative justice, 94; Wright, Restorative justice, 355.

21 Zehr, Changing lenses, 33.

22 Roche, Accountability in restorative justice, 9.

$23 \mathrm{~S}$ Herman, Is restorative justice possible without a parallel system for victim?, in $\mathrm{H}$ Zehr and B Toews (eds), Critical issues in restorative justice, Collompton: Willan Publishing, 2004, 75.

24 L Walgrave, Restorative justice, self-interest and responsible citizenship, Collompton: Willan Publishing, 2008, 116.

25 Roche, Accountability in restorative justice, 2, 28.

26 DL Gustafson, Is restorative justice taking too few, or too many, risks?, in Zehr and Toews (eds), Critical issues in restorative justice, 306. 
27 L Sherman and H Strang, Restorative justice: The evidence, Smith Institute, 2007, 13.

28 Ibid., 21, 68.

$29 \mathrm{~J}$ Dignan, Evaluating restorative justice from a victim perspective: empirical evidence, in C Hoyle (ed.), Restorative justice: critical concepts in criminology, Volume III, London: Routledge, 2010, 8.

30 Van Ness and Strong, Restoring justice, 69.

31 See Zehr, Changing lenses, 188; C Cunneen and C Hoyle, Debating restorative justice, Portland: Hart Publishing, 2010, 19; R Koen, The antinomies of restorative justice, in $E$ van der Spuy, S Parmentier and A Dissel (eds), Restorative justice: politics, policies and prospects, Cape Town: Juta, 2007, 257.

$32 \mathrm{~J}$ Latimer, C Dowden and D Muise, The effectiveness of restorative justice practices: a meta-analysis, The Prison Journal, 2005, 137.

33 Sherman and Strang, Restorative justice, 4, 64.

34 Koen, The antinomies of restorative justice, 260.

35 Latimer, Dowden and Muise, The effectiveness of restorative justice practices, 136; MS Umbreit, RB Coates and B Vos, Victim offender mediation: an evolving evidence-based practice, in D Sullivan and L Tifft (eds), Handbook of restorative justice, London: Routledge, 2006, 56; Sherman and Strang, Restorative justice, 62; Van Ness and Strong, Restoring justice, 69; RA Elias, Restorative justice in domestic violence cases, DePaul Journal for Social Justice, 9, 2015, 78.

36 Sherman and Strang, Restorative justice, 24.

37 Ibid., 52.

38 See FF Rosenblatt, Community involvement in restorative justice: lessons from an English and Welsh case study on youth offender panels, Restorative Justice: An International Journal, 2:3, 2014, 288; M Rossner and J Bruce, Community participation in restorative justice: rituals, reintegration and quasi-professionalization, Victims \& Offenders, 11:1, 2016, 111.

39 See J Johnstone, Restorative justice: ideas, values and debates, $2^{\text {nd }}$ edition, New York: Routledge, 2011, 25.

40 Ibid., 25.

$41 \mathrm{H}$ Zehr, The little book of restorative justice, Intercourse: Good Books, 2002, 26; JG Brown, The use of mediation to resolve criminal cases: a procedural critique, in D Roche (ed.), Restorative justice, Dartmouth: Ashgate Publishing, 2004, 201; $\mathrm{H}$ Zehr and $\mathrm{H}$ Mika, Fundamentals of restorative justice, in Roche (ed.), Restorative justice, 74.

42 H Strang, Repair or revenge: victims and restorative justice, New York: Oxford University Press, 2002, 204; M Keenan, E Zinsstag and C O'Nolan, Sexual violence and restorative practices in Belgium, Ireland and Norway: a thematic analysis of country variations, Restorative Justice: An International Journal, 4:1, 2016, 87.

43 Lees regards the hearing of sex abuse cases in ordinary courts as a form of 'judicial rape' in terms of inflicting further trauma on victims. See S Lees, Judicial rape, Women's Studies International Forum, 16:1, 1993, 11. See also D Stuart, No real harm done: sexual assault and the criminal justice system, paper presented at the 'Without consent: confronting adult sexual violence' conference, Australian Institute of Criminology, Canberra, 27-29 October 1992, 101; M Keenan, E Zinsstag and C O'Nolan, Sexual violence and restorative practices in Belgium, Ireland and Norway: a thematic analysis of country variations, Restorative Justice: An International Journal, 4:1, 2016, 90.

44 MC Doyle, Circles of trust: using restorative justice to repair organisations marred by sex abuse, Pepperdine Dispute Resolution Law Journal, 14, 2014, 177; Keenan, Zinsstag and
O'Nolan, Sexual violence and restorative practices in Belgium, Ireland and Norway, 92.

45 Zehr, Little book of restorative justice, 13.

46 See MA Walters, Hate crime and restorative justice, Oxford: Oxford University Press, 2014, 55.

47 See Zehr, Little book of restorative justice, 9; LW Sherman and H Strang, Restorative justice: the evidence, Smith Institute, 2007, 21, 68. In the United States, a victim whose daughter had been violently killed by her boyfriend volunteered to meet the offender in order to understand why the offender had committed the crime. Interestingly, at the end of the mediation process, the victim's family recommended to the court that the offender should receive a lesser sentence (5-15 years). The recommendations by the restorative conference were partly upheld by the court, which sentenced the offender to 20 years in prison. See CL Lyons, Restorative justice: can it help victims and rehabilitate offenders?, CQ Researcher, 26:6, 2016, 126-7.

48 L Walgrave, Domestic terrorism: a challenge for restorative justice, Restorative Justice: An International Journal, 3:2, 2015, 285.

49 Strang, Repair or revenge, 205.

50 L Wolhuter, N Olley and D Denham, Victimology: victimisation and victims' rights, London and New York: RoutledgeCavendish, 2009, 224.

51 Restorative justice proponents would argue that these rights can be maintained through a consensus agreement.

52 Cunneen and Hoyle, Debating restorative justice, 142.

53 A Skelton and M Batley, Charting progress, mapping the future: restorative justice in South Africa, Restorative Justice Centre, 2006, 9.

54 A Skelton and C Frank, How does restorative justice address human rights and due process issues?, in Zehr and Toews (eds), Critical issues in restorative justice, 206.

55 Brown, The use of mediation to resolve criminal cases, 201.

56 Skelton and Frank, How does restorative justice address human rights?, 206.

57 KE Bloch, Reconceptualising restorative justice, Hastings Race and Poverty Law Journal, 7, 2010, 209.

58 United Nations, Economic and Social Council (ECOSOC) Resolution 2002/12: Basic principles on the use of restorative justice programmes in criminal matters, 2002, http://www. un.org/en/ecosoc/docs/2002/resolution\%202002-12.pdf (accessed 12 March 2018); J Latimer, C Dowden and D Muise, The effectiveness of restorative justice practices: a metaanalysis, The Prison Journal, 2005, 128; Skelton and Batley, Charting progress, mapping the future, 10; B Naude and D Nation, An analysis of cases referred to restorative justice in Tshwane Metropolitan area, Acta Criminologica, 20:2, 2007, 142; H Hargovan, Knocking and entering: restorative justice arrives at the courts, Acta Criminologica, 1, 2008, 30; Cunneen and Hoyle, Debating restorative justice, 101.

59 Post-sentencing restorative justice, which is normally run as a prison programme.

60 The use of restorative justice processes is common in juvenile justice and minor offences involving adult offenders. However, restorative justice in prisons has been very useful in dealing with violent offences, which are rarely subjected to restorative intervention at pre-trial or pre-sentencing stage. Truth and reconciliation commissions, as a form of restorative intervention, have been used to bring together victims of and offenders in mass atrocities.

61 G Maxwell, Diversionary policing of young people in New Zealand: a restorative approach, in G Maxwell and JH Liu (eds.), Restorative justice and practices in New Zealand: towards a restorative justice, Eugene: Wipf and Stock Publishers, 2007, 111; FWM McElrea, Restorative justice for 
adult offenders: practice in New Zealand today, in Maxwell and Liu (eds), Restorative justice and practices in New Zealand, 96.

62 In the United Kingdom, police cautioning, which is popular in the Thames Valley police cautioning programme, is provided by the Criminal Justice Act 2003, as amended in 2006. See G Maxwell, The defining features of a restorative justice approach to conflict, in Maxwell and Liu (eds), Restorative justice and practice in New Zealand, 111; See also RA Braddock, Rhetoric or restoration? A study into the restorative potential of the conditional cautioning scheme, International Journal of Police Science and Management, 13:3, 2011, 196.

63 S Dennison, A Stewart and E Hurren, Police cautioning in Queensland: the impact of juvenile offending pathways, Trends and Issues in Crime and Criminal Justice, 306, 2006, 2.

64 South Africa, Child Justice Act 2008 (Act 75 of 2008), section 41.

65 Ibid., section 52.

66 Ibid., section 42.

67 See S v Shulubane 2008 (1) SACR 295 (T); S v Maluleke 2008 (1) SACR (T).

68 South Africa, Criminal Procedure Act 1997 (Act 51 of 1977), section 274.

69 The same provision is also found in the Criminal Procedure Act of Tanzania, section 236, but is never used for restorative justice purposes. The practice indicates that, after the offender's conviction, the magistrate can adjourn the case until another day to deliver the sentence. Where the magistrate proceeds to sentence the offender immediately after conviction, in most cases he or she will only request that mitigating factors be included in the sentence. Countries that have realised the importance of restorative justice use this time as an opportunity for restorative intervention, and this is when other information such as victim impact statements are presented to the magistrate for sentencing purposes.

70 See Skelton and Batley, Charting progress, mapping the future, 44.

71 Ibid., 44.

72 Ugandan Executive Committees (Judicial Powers) Act, sections 6, 28.

73 See Ugandan Children's Statute, section 92; Ugandan Local Council (Judicial Powers) Act, sections 19, 20; LT Ekirikubinza, Juvenile justice and the law in Uganda: operationalisation of the Children's Statute, International Survey of Family Law, 2005, 516.

74 See Ekirikubinza, Juvenile justice and the law in Uganda, 515-6.

75 C Banks, Protecting the rights of the child: regulating restorative justice and indigenous practices in Southern Sudan and East Timor, International Journal of Children's Rights, 19, 2011, 168; MO Ensor, African children's right to participate in their own protection: perspective from South Sudan, International Journal of Children's Rights, 22, 2014.

76 Southern Sudan, Child Justice Act 2008, sections 3, 4.

77 See Kenya, Children Act No. 8 of 2001, section 191(1).

78 Law of the Child (Juvenile Court Procedure) Rules of 2016, Rule 50(3)(vii).

79 The Law of the Child Act (2009), section 119.

80 The Law of the Child (Juvenile Court Procedure) Rules (2016), Rule 51.

81 Ibid., Rule 52.

82 Ibid., Rule 50.

83 Ibid., Rule 54.

84 See Qhubu, The development of restorative justice in Lesotho, 1; EA Foley, It still 'takes a village to raise a child': an overview of restorative justice mechanism under the Children's
Protection and Welfare Act, 2011 Lesotho, Article 40, 16:1, 2014, 16

85 The aims of restorative justice under Lesotho's Children's Protection and Welfare Act 2011 (Act 7 of 2011) are provided under section 120 .

86 lbid., section 2 .

87 The Constitution of the United Republic of Tanzania, Article 107A.

88 Ibid., Article 107B.

89 Ibid., Article 107A (2) (c).

90 Ibid., Article 107A (d).

91 Ibid., Article 107A (e).

92 Tanzania, Criminal Procedure Act, section 163.

93 Ibid., section 163.

94 Ibid., section 163.

95 Ibid., section 163.

96 Ibid., section 163.

97 In Tanzania, the Primary Courts Criminal Procedure Code only applied in primary courts. Primary courts are the lowest courts within the judicial ladder. In the District Court, the Court of Resident Magistrate and the High Court, the Criminal Procedure Act governs criminal procedures. The Court of Appeal of Tanzania is governed by the Court of Appeal Rules of 2009.

98 The Third Schedule to The Magistrates' Court Act, Rule 4(2).

99 Under Rule 23 of the Primary Courts Criminal Procedure Code.

100 According to the Handbook on restorative justice programmes, New York: United Nations Office on Drugs and Crime, 2006, 7.

101 The Ward Tribunals Act Chapter 206, Revised Edition, 2002. A ward can be composed of two to four villages. According to the Local Government (District Authorities) Act, Chapter 287, Revised Edition, section 29, every district is divided into wards, as the District Council may determine.

102 Tanzania, Ward Tribunals Act, sections 3, 8(1) (2), 16(1).

103 Ibid., sections 8(1) (2), 16 (1); K Mader and G Bialluch (eds), Ward tribunals: how to enhance the rule of law at local levels, Support for Local Governance Processes (SULGO), Paper, 2010, 3, http://www.sulgo.or.tz/uploads/media/ Ward_Tribunals.pdf (accessed 9 November 2015).

104 YQ Lawi, Justice administration outside the ordinary courts of law in mainland Tanzania: the case of ward tribunals in Babati District, African Studies Quarterly, 1, 1997, 1.

105 Ward Tribunals Act, section 4.

106 Ibid., section 14; Mader and Bialluch (eds), Ward tribunals, 5.

107 Ward Tribunals Act, section 15.

108 Mader and Bialluch (eds), Ward tribunals, 5.

109 Ward Tribunals Act, section 20.

110 lbid., sections 8(1) (2), 16(1).

111 Lawi, Justice administration outside the ordinary courts of law in mainland Tanzania, 10.

112 C Nyamu-Musembi, Review of experience in engaging with 'non-state' justice systems in East Africa, Institute of Development Studies (IDS), February 2003, http://gsdrc.ids. ac.uk/docs/open/DS37.pdf (accessed 12 July 2017).

113 See Tanzania Human Rights Report 2016, 157.

114 See allAfrica, Tanzania: joy as 5678 prisoners obtain presidential pardon, 10 December 2016, http://allafrica.com/ stories/201612120551.html (accessed 12 July 2017).

115 See T Gavrielides, The truth about restorative justice in prisons, Prison Service Journal, 228, 2016, 44. 